\title{
Hydrology, Plankton, and Corals of the Maracajaú Reefs (Northeastern Brazil) - an Ecosystem Under Severe Thermal Stress
}

\author{
Elga Miranda Mayal $^{1}$, Sigrid Neumann-Leitão ${ }^{2 *}$, Fernando Antônio do Nascimento \\ Feitosa $^{2}$, Ralf Schwamborn ${ }^{1,4}$, Tâmara de Almeida e Silva ${ }^{3}$ and Maria da Glória Gonçalves \\ da Silva-Cunha ${ }^{2}$ \\ ${ }^{1}$ Departamento de Zoologia; Universidade Federal de Pernambuco; 50670-901; Recife - PE - Brasil. \\ ${ }^{2}$ Departamento de Oceanografia; Universidade Federal de Pernambuco; 50670-901; Recife - PE - Brasil. \\ ${ }^{3}$ Universidade do Estado da Bahia; Paulo Afonso - BA - Brasil. ${ }^{4}$ Alfred Wegener Institute for Polar and Marine \\ Research; Bremerhaven - Germany
}

\begin{abstract}
This study provides baseline information on the hydrological conditions and on the coral and plankton communities at the Maracajaú reef ecosystem (Northeastern Brazil). Studies were performed from February to June 2000, covering the transition from dry to rainy season. In this area, there is an offshore coral reef formation, where corals were observed in loco; the water samples were collected to obtain the hydrological and plankton data. Six scleractinian species were identified. Stable isotope analysis on the carbonate fraction of Favia gravida fragments showed that these corals were under severe thermal stress. Chlorophyll-a varied from 1.1 to $9.3 \mathrm{mg} \mathrm{m}^{-3}$, with higher values during the rainy season. Average zooplankton wet weight biomass were 117.0 (microzooplankton) and 15.7 $m g \mathrm{~m}^{-3}$ (mesozooplankton). A total of 136 Phytoplankton and 61 zooplankton taxa were identified. Seasonal forcing determined the phyto- micro- and mesozooplankton community structure, rather than the coastal-offshore gradient.
\end{abstract}

Key words: Coral reefs, hydrology, plankton, thermal stress, human impacts

\section{INTRODUCTION}

Reefs constitute the foundation of immensely complex marine coastal communities of fundamental value and are among the most productive marine ecosystems (New, 1995). Although geographically restricted to tropical seas and occupying only $0.1 \%$ of the earth surface, coral reefs have globally important implications for the marine biodiversity. Reefs support unusually diverse floral and faunal communities with distinctive taxonomic structure and geographical distribution patterns (Kohn, 1997).

Brazilian coral reefs are distributed in a noncontinuous narrow band along approximately 3,000 km of the Atlantic coastline, from the State of Maranhão to the State of Bahia. Though not as diverse as the Great Barrier Reef in Australia, Brazilian reefs have eight endemic species of corals (Castro and Pires, 2001; Prates, 2003).

All reef in which corals grow or grew in Northeastern Brazil, have a base of sandstone or

\footnotetext{
* Author for correspondence: sigrid@terra.com.br
} 
sometimes another rock type cropping out of the sea floor. Where corals occur, there is also a great profusion of algae, which usually grow on the seaward side of the reef, where the wave action is strong (Laborel, 1965). Although the reefs are not completely composed of corals, they have important roles in protecting many low - lying shores from erosion, supporting fisheries, enhancing tourism, and as sources of items for the souvenir and aquarium trades and provide building material (Goreou et al., 1979; Leão et al., 2003). Coral reef organisms can tolerate only a narrow range of environmental conditions and are sensitive to environmental changes (Richmond, 1993). They tolerate relatively narrow ranges of temperature, salinity, water clarity, and other chemical and water quality characteristics (Wells, 1957). Reefs, thus, are excellent sentinels of the quality of their environment. Proper monitoring of reefs can identify changes in water quality or impacts from land based activities.

Reefs are good environmental quality indicators because even very slight changes in the hydrology and many anthropogenic impacts may result in community structure changes. The impact of increased sedimentation (from logging, land clearing, deforestation etc.), coastal eutrophication, and increased temperature (global warming) are probably the most common and serious negative influences on coral reefs and their associated fauna and flora in Brazil (Maida and Ferreira, 1997; Castro and Pires, 2001; Leão et al., 2003).

The Maracajaú area was first studied by Laborel (1969) who mentioned coral occurrence besides other fauna and flora organisms. Feitosa et al. (2003) studied the reef fish fauna and Testa (1997) carried out studies about the calcareous algae and corals at Sioba and Rio do Fogo beach, to the north of the present study area. In Brazil, a general review of the coral reefs including all the published papers was made by Leão et al. (2003), which showed a paucity of studies in the Maracajaú area.

The goals of this study were to provide the baseline information on the hydrological conditions and on the coral and plankton communities at the Maracajaú reef ecosystem, as well as to assess the effect of thermal stress on the reef.

Results could help to assess the anthropogenic disturbances and assist decision making processes by helping the local resource managers to understand the implications of actions associated with the particular coral communities. These connections could also help in developing the management plans for the coral reefs and other coastal and marine resources in Brazil.

\section{MATERIAL AND METHODS}

\section{Study area}

The Maracajaú reef ecosystem is located off Rio Grande do Norte State, Northeastern Brazil ( $5^{\circ} 21^{\prime} 12^{\prime \prime} \mathrm{S}, 5^{\circ} 25^{\prime} 30^{\prime \prime} \mathrm{S}$ and $35^{\circ} 14^{\prime} 30^{\prime \prime} \mathrm{W}, 35^{\circ} 17^{\prime}$ $\left.12^{\prime \prime} \mathrm{W}\right)$. In this area, there is an extensive offshore reef formation, where the "APA dos Recifes de Corais", a marine protected area (MPA), was established in June 2001. This MPA has been built on integrated participative management supported by the research and monitoring. During low tide, these reefs are generally at 0.5 to $2.0 \mathrm{~m}$ depth, while in some places they may reach a depth of 3.0 meters. This formation is surrounded by shallow waters $(\mathrm{z}<10 \mathrm{~m})$ and extends approximately through an area of $10 \mathrm{~km} \times 4 \mathrm{~km}$. The reefs are located approximately 5 to $7 \mathrm{~km}$ offshore from the sandy beaches of Maracajaú (Fig. 1). According to Leão et al. (2003), these "pinnacle" formations resemble large hats with broad brims, referring to this unique coral growth form that consists of isolated narrow pillars whose apices are expanded laterally. Most of the reef base is constituted of fossilized calcareous algae, corals and vermetids. This distinctive reef ranges from 5 to $25 \mathrm{~m}$ in height above the seafloor, and from 5 to $50 \mathrm{~m}$ in reef top diameter.

The coast presents intense marine erosion and sharp cliffs that belong to the Barreiras Formation. Approximately $2 \mathrm{~km}$ from the coast, there is a $5 \mathrm{~m}$ to $10 \mathrm{~m}$ deep channel (Fig. 1). Most of the bottom areas are covered with remnants of calcareous algae, except for the channel, which is covered by sea grass beds (Halodule wrightii). The coastal area is influenced by a small river (Rio Maxaranguape). The Rio Maxaranguape may show a short period of strong runoff during the rainy season (March to August) but is reduced to a small creek during the dry season (September to February). 


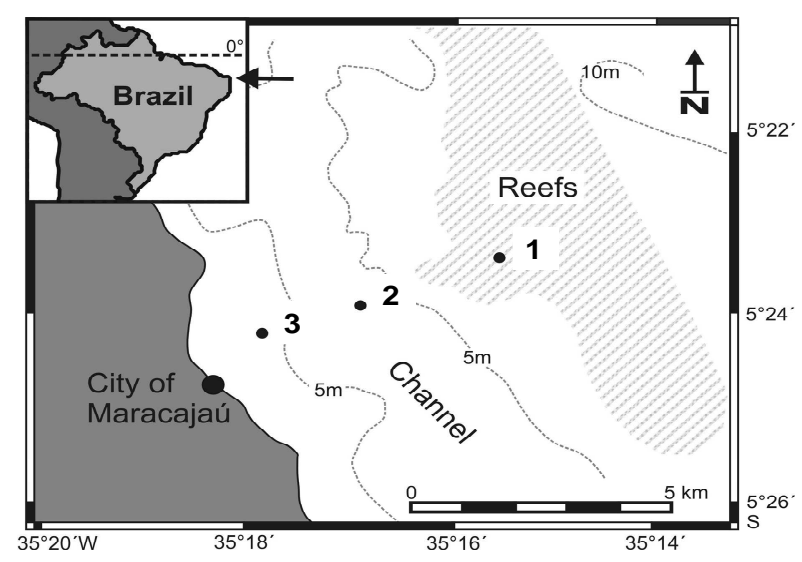

Figure 1 - Study area showing sampling stations 1 to 3 off Maracajaú (Rio Grande do Norte State, Northeastern Brazil).

The Maracajaú "pinnacle" reef includes three regions: the reef crest (the part of the reef the waves break over), the fore reef (region of medium energy), and the spur and groove or buttress zone (the region of coral growth which includes the rows of corals with sandy canyons or passages between each row). Sediments of the region are composed of a mix of siliclastic $(\sim 60 \%)$ and carbonate silt $(\sim 40 \%)$, mainly derived from Penicillus, rich in sponge spicules. The sea grass beds in the channels are inserted by living rhodoliths (Testa, 1997).

\section{Methodology}

A wide range of scientific methods was used to survey the reefs. Corals were identified and photographed in loco by scuba diving. To evaluate the thermal stress and the production of zooxanthellae, coral (Favia gravida) colonies were collected with chisel and hammer. This species was chosen as indicator for the thermal stress due to its high sensitivity. The collected specimens were transported in plastic containers to the laboratory, where they were washed with tap water, placed in $15 \%$ hydrogen peroxide to remove any organic matter, rinsed with distilled water and left to dry at room temperature.

Stable carbon $\left(\delta^{13} \mathrm{C}\right)$ and oxygen $\left(\delta^{18} \mathrm{O}\right)$ isotopes of carbonate skeletons of $F$. gravida were analyzed at the stable isotope laboratory (LABISE) of the Department of Geology of the Federal University of Pernambuco. Carbonate samples from skeletons were micro-drilled (20 to $40 \mathrm{mg}$ ) and placed to react with anhydrous phosphoric acid for $12 \mathrm{~h}$ at $25^{\circ} \mathrm{C}$ (McCrea, 1950). Carbon dioxide $\left(\mathrm{CO}_{2}\right)$ released from this reaction was extracted in a high vacuum line, cryogenically cleaned and analyzed in a dual inlet, triple collector mass spectrometer (SIRA II), using Borborema skarn calcite (BSC) as a laboratory standard. The external precision, based on multiple standard measurements of NBS standard -19 , was better than $0.1 \%$ for carbon and oxygen. The results were expressed in the international PDB scale (Craig, 1957). Local water temperature was estimated assuming that $\delta^{18} \mathrm{O}$ of the local water was zero, and using the Horibe and Oba (1972) equation for aragonite. The $\delta^{13} \mathrm{C}$ measurements were performed as a tool to investigate the productivity of coral zooxanthellae. Hydrological and plankton data were obtained at three fixed stations along a transect perpendicular to the coast (Stations 1 to 3, Fig. 1). The stations were chosen according to the following strategy: Station 1 - located on the reef top; Station 2 located at the channel (covered by the seagrass Halodule wrightii); and Station 3 - near the shore, receiving maximum continental influence. To evaluate the seasonal effects, samples were taken twice during the dry (February and March 2000) and rainy (May and June 2000) seasons. Sampling was always performed during the spring low tides. Local depth was measured with an echo sounder. Water transparency was estimated with a Secchi disc. Water samples for hydrology and the determination of planktonic primary production were collected at the surface with a 5-litre Nansen bottle. The following variables were measured: temperature (digital thermometer); salinity (MohrKnudsen method); dissolved oxygen (Winkler method according to Strickland and Parsons, 
1965); pH (pHmeter Hanna, model 8417); dissolved nutrients and suspended matter (standard methods according to Strickland and Parsons, 1972 and Grasshoff et al., 1983). Chlorophyll $a$ concentration was determined in the laboratory after filtration over GFF filters and extraction with acetone (Parsons and Strickland, 1963). Phytoplankton primary productivity was measured by the ${ }^{14} \mathrm{C}$ method (Steemann-Nielsen, 1952). Phytoplankton assimilation rate was calculated according to Vollenweider et al. (1974). Microand Mesozooplankton samples were collected with two plankton nets $(65 \mu \mathrm{m}$ and $300 \mu \mathrm{m}$ mesh size, respectively), which were towed horizontally for 3 minutes at sub-surface. A flowmeter (Hydrobios, Kiel) was fitted on the opening of each net. Samples were preserved in a $4 \%$ buffered formaldehyde/seawater solution. In the laboratory, plankton biomass was estimated by the wet weight (WW) method (Omori and Ikeda, 1984). Phytoplankton and zooplankton were identified until the lowest taxonomic unit possible.

To test the effects of seasonal forcing and coastaloffshore gradients on central pelagic processes in the area, a one-way Kruskall-Wallis ANOVA (Zar, 1996) was performed at $\alpha=0.05$ with main plankton data (chlorophyll $a$, phyto-, micro- and mesozooplankton biomass and density) as dependent variables. The factors "Month" (4 factor levels) and "Station" (3 factor levels) were used as independent variables separately, without considering the interactions between the factors. To test for the existence of discontinuities in zooplankton community structure in time and space, multidimensional scaling (MDS) was performed, based on density data (Clarke and Warwick, 1994). Micro- and mesozooplankton were analyzed separately. MDS plots were generated based on Bray-Curtis similarities between samples, after square-root transformation and standardization (Clarke and Warwick, 1994). MDS plots are two-dimensional projections of the (n-dimensional) similarities between the samples. Stress values were calculated to assess the accuracy of the projection, where stress values below 0.2 were considered acceptable (Clarke and Warwick, 1994). Only groups that appeared in MDS plots and corresponding Cluster diagrams as well were accepted. The a priori hypotheses that the groups of samples were formed according to the factors "Month" and "Station", were tested for micro- and mesozooplankton separately, using one-way ANOSIM ("Analysis of Similarities") permutation tests (Clarke and Warwick, 1994). ANOSIM was run with 999 permutations at $\alpha=$ 0.05. MDS, Cluster analysis and ANOSIM were performed using the PRIMER Software (Version 5.2. PRIMER-E, Ltd.).

\section{RESULTS}

\section{Coral species composition}

Six coral species were identified in the Maracajaú reef system: Agaricia agaricites (Linnaeus) 1758, Siderastrea stellata Verrill, 1868, Porites astreoides Lamarck, 1816, P. branneri Rathbun, 1887, Favia gravida Verrill, 1868, and Mussismilia hispida (Verrill, 1902). S. stellata was the most abundant species on the reef top, while $M$. hispida dominated the reef walls.

The corallites generally reached up to $4 \mathrm{~mm}$ in diameter, and sometimes up to $5-7 \mathrm{~mm}$. They were round and deep. In shallow areas, the corallites presented higher diameter and the fifth cycle of septa was united to the fourth cycle (Mayal et al., 2000). The most common live color at Maracajaú was orange. S. stellata is widely distributed along the entire Brazilian coast from the Northeast down to Rio de Janeiro (Mayal et al., 2000).

M. hispida (Familiy Mussidae) occurred at the pinnacle walls and the colonies were massive and not well developed, with less than $0.5 \mathrm{~m}$ high and usually flattened. Corallites were round with thick walls and $10-15 \mathrm{~mm}$ diameter. Septa of living colonies were round, bead - like dentations. Many colonies were completely bleached.

A. agaricites (Family Agariciidae) presented discoid colonies. The corallites were arranged in parallel groups. The serrulate septa numbering from 30 to 33 were green and brown (Mayal et al. 2000). In Maracajaú, the predominant color was brown.

P. astreoides (Family Poritidae) presented small hemispheric colonies, preserving massive protuberances. This species formed yellow or green lumpy masses, which generally grew to about $36 \mathrm{~cm}$ in diameter and occurred in shallow water.

P. branneri had corallites with a diameter of up to $1.5 \mathrm{~mm}$. The septae were porous, with the internal edge fused forming a central ring. This species did not show columellae. Colonies were found 
incrusting and composed of round massive forms, commonly with mamelonated polyps (Mayal et al., 2000).

F. gravida (Family Faviidae) presented a plane form, meandering with no elevation pattern and very similar to those occurring at Rocas Atoll (Mayal et al., 2000). The number of septa per corallite varied with size and meandrization; there were teeth over all the septum extension. The columella was very small and the mounds were high and separated. The wall was compact and in some specimens they were high, allowing total view.

\section{Stable isotope analysis}

The $\delta^{13} \mathrm{C}$ values measured in the carbonate fraction of $F$. gravida showed very little variation between the samples, ranging from -4.38 to $-4.08 \%$ PDB (Table 1). The $\delta^{18} \mathrm{O}$ values showed a much higher variation, ranging from -2.49 to $-0.85 \%$ PDB. The ${ }^{18} \mathrm{O}$ temperature, calculated directly from $\delta^{18} \mathrm{O}$ values, ranged from 33.1 to $35.9^{\circ} \mathrm{C}$, with an average of $34.5^{\circ} \mathrm{C}$.

Table 1 - Stable isotope values $\left(\delta^{18} \mathrm{O}\right.$ and $\left.\delta^{13} \mathrm{C}\right)$ measured in the carbonate fraction of $F$. gravida from the Maracajaú reefs (Brazil). Temperature was calculated based on $\delta^{18} \mathrm{O}$ values, using the equations of Horibe and Oba (1972).

\begin{tabular}{cccc}
\hline Specimen & $\boldsymbol{\delta}^{\mathbf{1 3}} \mathbf{C}\left(\boldsymbol{\%}_{\mathbf{O P D B}}\right)$ & $\boldsymbol{\delta}^{\mathbf{1 8}} \boldsymbol{( \boldsymbol { \% } _ { \mathbf { O P D B } } )}$ & $\boldsymbol{\delta}^{\mathbf{1 8}} \mathbf{O}$ temperature $\left({ }^{\mathbf{0}} \mathbf{C}\right)$ \\
\hline 01 & -4.08 & -1.88 & 33.1 \\
02 & -4.08 & -0.85 & 35.1 \\
03 & -4.26 & -1.61 & 33.9 \\
04 & -4.38 & -2.27 & 34.5 \\
05 & -4.23 & -2.49 & 35.9 \\
\hline
\end{tabular}

\section{Hydrology}

Hydrological data obtained showed marked seasonal variations for some parameters (e.g. plankton primary productivity), while others (e.g. dissolved oxygen concentration) remained virtually unchanged during the study period (Table 2). The region is consistently bathed by the warm South Equatorial Current (SEC). Water temperatures varied little throughout the year, ranging from 26.5 to $29^{\circ} \mathrm{C}$. Seasonal temperature amplitude was approx. $2^{\circ} \mathrm{C}$ (Table 2). As expected, salinity slightly decreased during the rainy season. Water transparency clearly decreased in the transition from the dry to rainy season, with Secchi depths ranging from $1 \mathrm{~m}$ (May, station 3) to $7.8 \mathrm{~m}$ (February, station 2). The $\mathrm{pH}$ was always alkaline (>8). Concentrations of dissolved oxygen varied from $4.26 \mathrm{ml} \mathrm{L}^{-1}$ (June, station 1) to $6.16 \mathrm{ml}$ $\mathrm{L}^{-1}$ (February, station 1), without a clear seasonal pattern. As expected, the surface water was always clearly oversaturated. Nitrite concentrations were always below $0.05 \mu \mathrm{mol} \mathrm{L} \mathrm{L}^{-1}$, with little variation. Nitrate concentrations varied from $0.04 \mu \mathrm{mol} \mathrm{L}^{-1}$ (June, station 2) to $1.79 \mu \mathrm{mol} \mathrm{L} \mathrm{L}^{-1}$ (February, station 1), without a clear seasonal pattern. Phosphate and silicate concentrations increased during the transition from dry to rainy season
(Table 2). Phosphate varied from $0.05 \mu \mathrm{mol} \mathrm{L}{ }^{-1}$ (February, station 3) to $0.20 \mu \mathrm{mol} \mathrm{\textrm {L } ^ { - 1 }}$ (May, station 3), and silicate from $2.38 \mu \mathrm{mol} \mathrm{\textrm {L } ^ { - 1 }}$ (February, station 2) to $10.98 \mu \mathrm{mol} \mathrm{L} \mathrm{L}^{-1}$ (June, station 3). Total suspended solids also presented higher values during the rainy season, varying from $5 \mathrm{mg} \mathrm{L}^{-1}$ (February, station 1) to $30 \mathrm{mg} \mathrm{L}^{-1}$ (May, station 3).

\section{Chlorophyll- $a$ and Primary productivity}

Chlorophyll- $a$ concentrations, phytoplankton primary productivity and assimilation rates increased from the dry to the rainy season. Chlorophyll- $a$ concentrations varied from 1.12 mg. $\mathrm{m}^{-3}$ (February, station 3) to $9.3 \mathrm{mg} \cdot \mathrm{m}^{-3}$ (May, station 3) (Fig. 2). Lowest primary productivity occurred during the dry season over the reefs $(3.56$ $\mathrm{mg}_{\mathrm{C}} \mathrm{m}^{-3} \mathrm{~h}^{-1}$, with an assimilation rate of $1.66 \mathrm{mg}_{\mathrm{C}} \mathrm{h}^{-}$ $\left.{ }^{1} \mathrm{mg}_{\mathrm{cl}}{ }^{-1}\right)$ and highest during the rainy season close to shore $\left(69.58 \mathrm{mg}_{\mathrm{C}} \mathrm{m}^{-3} \mathrm{~h}^{-1}\right.$, with an assimilation rate of $7.48 \mathrm{mg}_{\mathrm{C}} \mathrm{h}^{-1} \mathrm{mg}_{\mathrm{cla}}{ }^{-1}$ ). High phytoplankton productivity in coastal areas and low productivity offshore were characteristic features of this area.

Plankton biomass and community structure

A total of 136 phytoplankton taxa were identified (Table 3). Diatoms were the most abundant and 
diverse taxon, with 102 species, being more abundant in decreasing order the species: Chaetoceros curvisetus, Pseudosolenia calcaravis, Bleakeleya notata, Isthmia enervis, Prosbocia alata, Fragilaria capucina, Rhabdonema adriaticum, Podocystis adriatica, Bacillaria paxillifera, Asterionellopsis glacialis, Biddulphia biddulphiana, Chaetoceros lorenzianus and Guinardia striata. Dinoflagellates were present with 18 species, Ceratium furca being the most abundant and frequent.

Minimum phytoplankton density was 2,067 $10^{-3}$ cells $\mathrm{L}^{-1}$ (March, station 2) and maximum was 6,177 $10^{-3}$ cell $\mathrm{L}^{-1}$ (June, station 2) (Fig. 2). Average density was $3,158 \quad 10^{-3}$ cell $\mathrm{L}^{-1}$. A seasonal pattern was observed with the highest numbers occurring during the dry season.

Table 2 - Hydrological parameters and plankton primary productivity obtained at the Maracajaú reef system (Brazil) from February to June 2000. SD: standard deviation. $\mathrm{N}=6$ (3 stations, 2 months per season).

\begin{tabular}{lcccc}
\hline & \multicolumn{2}{c}{ Dry eason } & \multicolumn{2}{c}{ Rainy season } \\
\hline Parameters & Average & SD & Average & SD \\
\hline Depth $(\mathrm{m})$ & 5.1 & 2.8 & 4.5 & 2.1 \\
Secchi Depth $(\mathrm{m})$ & 4.0 & 2.4 & 3.0 & 1.8 \\
Temperature $\left({ }^{\circ} \mathrm{C}\right)$ & 28.97 & 0.08 & 27.22 & 0.79 \\
Salinity $(\mathrm{PSU})$ & 36.00 & 0.13 & 34.09 & 0.87 \\
pH & 8.73 & 0.06 & 8.14 & 0.07 \\
Dissolved oxygen $\left(\mathrm{ml} \mathrm{L}^{-1}\right)$ & 5.12 & 0.61 & 5.04 & 0.42 \\
Dissolved oxygen saturation $(\%)$ & 116.3 & 13.9 & 110.2 & 10.4 \\
Nitrite $(\mu \mathrm{mol} \mathrm{L})$ & 0.02 & 0.02 & 0.01 & 0.02 \\
Nitrate $\left(\mu \mathrm{mol} \mathrm{L}{ }^{-1}\right)$ & 0.78 & 0.51 & 0.57 & 0.42 \\
Phosphate $\left(\mu \mathrm{mol} \mathrm{L}^{-1}\right)$ & 0.08 & 0.02 & 0.16 & 0.04 \\
Silicate $(\mu \mathrm{mol} \mathrm{L})$ & 5.43 & 2.47 & 8.83 & 2.49 \\
Total suspended solids $\left(\mathrm{mg} \mathrm{L}^{-1}\right)$ & 7.2 & 3.9 & 13.3 & 8.5 \\
Clorophyll-a $\left(\mathrm{mg} \mathrm{m}^{-3}\right)$ & 2.2 & 2.3 & 4.0 & 4.0 \\
Plankton primary productivity $\left(\mathrm{mg}_{\mathrm{C}} \mathrm{m}^{-3} \mathrm{~h}^{-1}\right)$ & 11.0 & 13.5 & 34.1 & 42.4 \\
Assimilation rate $\left(\mathrm{mg}_{\mathrm{C}} \mathrm{h}^{-1} \mathrm{mg}_{\mathrm{Cla}}{ }^{-1}\right)$ & 3.5 & 4.1 & 5.6 & 6.5 \\
\hline
\end{tabular}
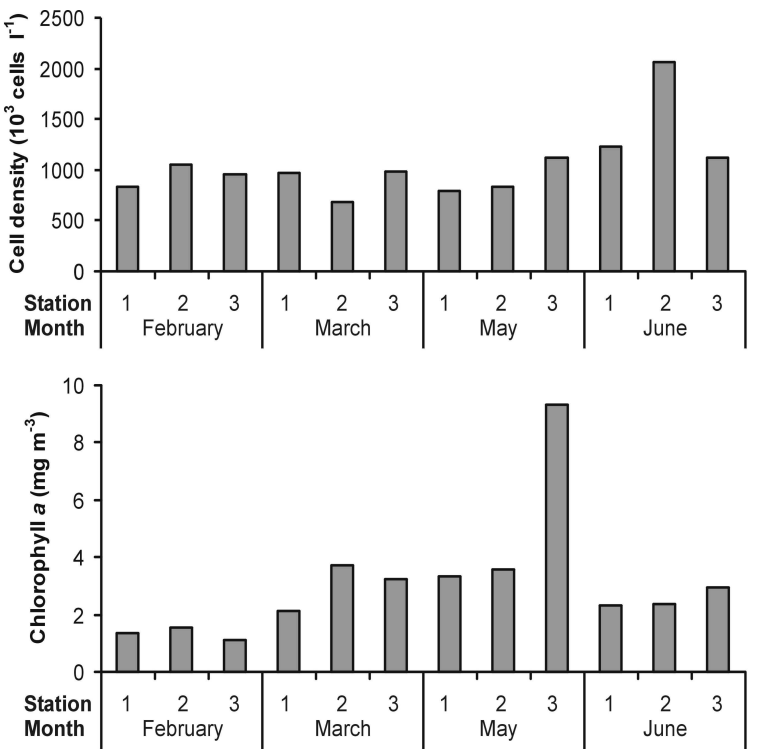

Figure 2 - Chlorophyll- $a$ concentration and phyto-plankton density in the sampling stations 1 to 3 off Maracajaú, Brazil. 
Table 3 - Phytoplankton species list of the Maracajaú reef ecosystem (Brazil).

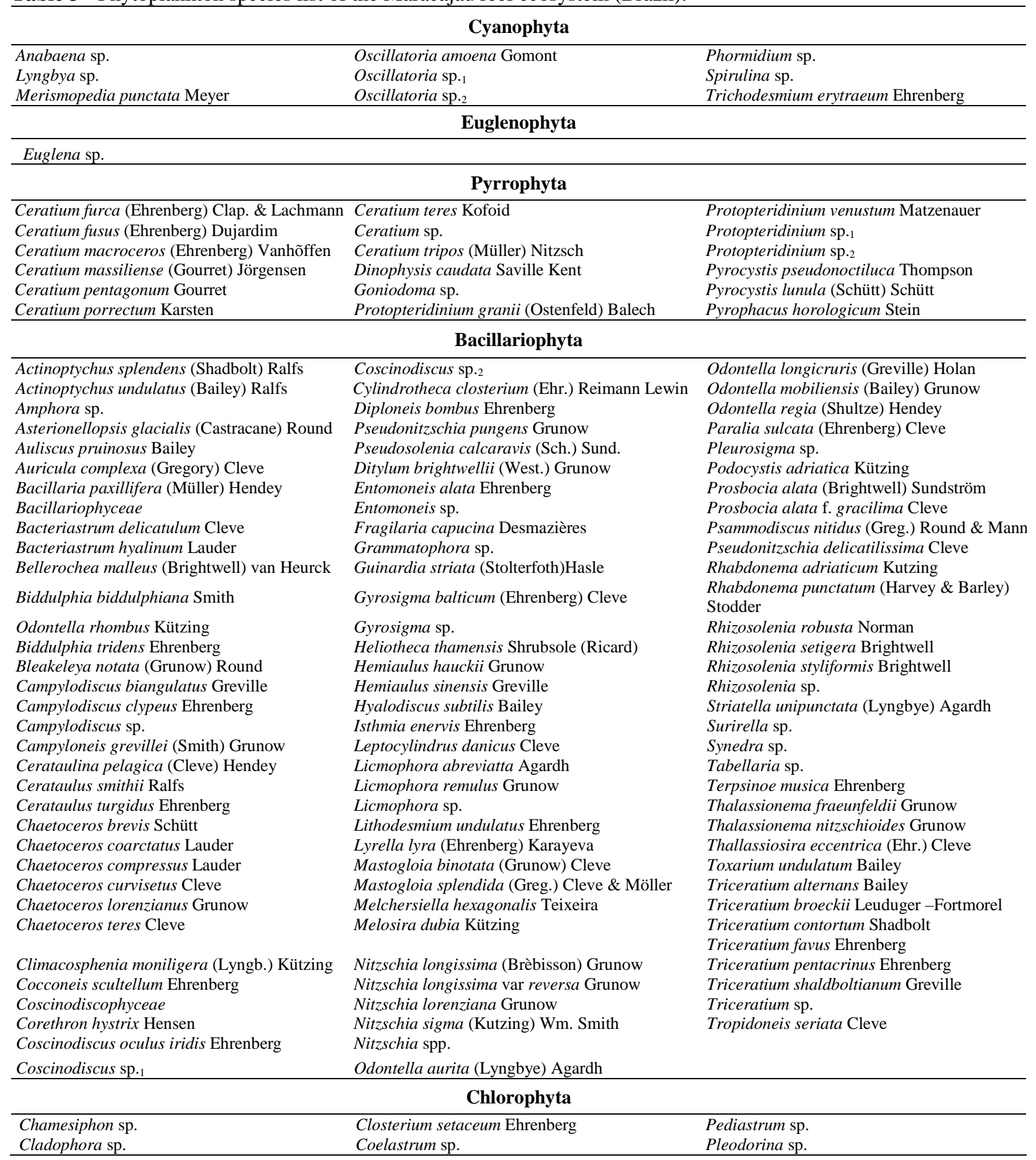

Plankton biomass in the microzooplankton fraction varied from $45.2 \mathrm{mg} \mathrm{m}^{-3}$ (June, station 1) to 316.5 $\mathrm{mg} \mathrm{m}^{-3}$ (March, station 1) (Fig. 3). In the mesozooplankton fraction, the biomass varied from $9.3 \mathrm{mg} \mathrm{m}^{-3}$ (March, station 1) to $43.2 \mathrm{mg} \mathrm{m}^{-3}$ (February, station 1). Overall average values were $117.0 \mathrm{mg} \mathrm{m}^{-3}$ (microzooplankton) and $15.7 \mathrm{mg} \mathrm{m}^{-3}$ (mesozooplankton). A sharp decrease in biomass was observed in the transition from rainy to dry season, both for microzooplankton and mesozooplankton (Fig. 3). This decrease was most evident nearshore (stations 3 and 2), but was also observed at station 1 .

A total of 61 zooplankton taxa were identified and counted (Table 4), with 50 taxa in the microzooplankton and 40 in the mesozooplankton 
fraction, and 20 taxa common to both the communities. Copepods showed the highest density and species richness (23 species), followed by Tintinnina ( 8 species). Holoplankton dominated $(65 \%)$ in the microzooplankton samples, while in the mesozooplankton, both holoplankton and merozooplankton were equally distributed. Copepods dominated in all the microzooplankton samples, followed by mollusk larvae (mainly bivalve). In the mesozooplankton, was observed the dominance of copepods and decapods larvae (mainly brachyuran zoeae).
The micro- and mesozooplankton followed a seasonal pattern, with the highest densities occurring through the dry season. Very high densities were found for the microzooplankton, varying from 1,917 ind $\mathrm{m}^{-3}$ (June, station 3) to 47,620 ind. ${ }^{-3}$ (February, station 2), with an average of 7,936 ind $\mathrm{m}^{-3}$. Microzooplankton density did not show a consistent spatial pattern, with maximum densities at station 2 in February, at station 1 in March and June, and at station 3 in May (Fig. 3).

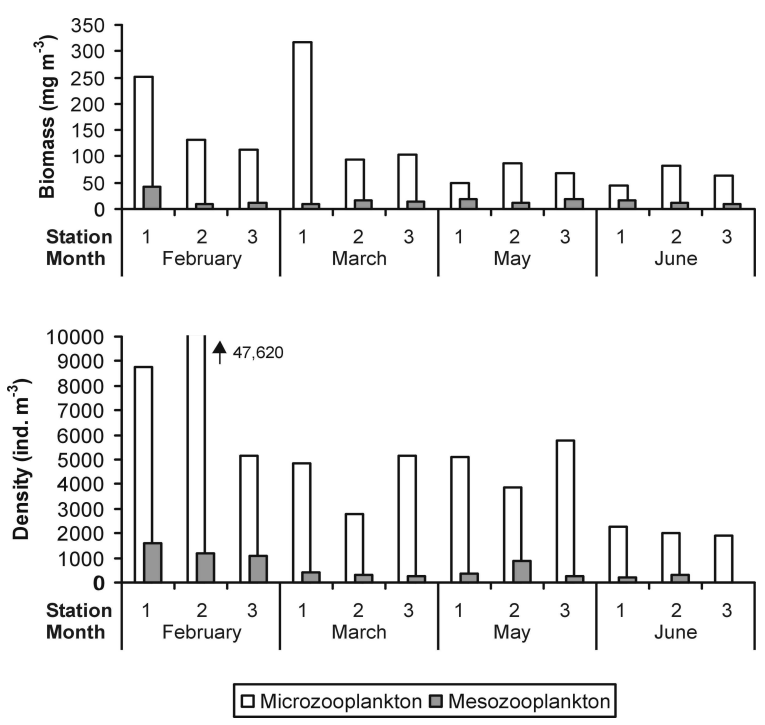

Figure 3 - Biomass and density of the micro-zooplankton $(65 \mu \mathrm{m})$ and meso-zooplankton (120 $\mu \mathrm{m})$ in the sampling stations 1 to 3 off Maracajaú, Brazil.

The contribution of the inshore zooplankton community to these peaks is indicated by the extreme abundance of the copepods (Parvocalanus crassirostris, Euterpina acutifrons, Oithona hebes) and bivalve larvae in the samples with high overall density. The mesozooplankton presented much lower densities, with a minimum of 92.4 ind $\mathrm{m}^{-3}$ (June, station 3) and a maximum of 1,617 ind $\mathrm{m}^{-3}$ (February, station 1), with an average of 579 ind $\mathrm{m}^{-3}$. Most taxa showed a seasonal cycle of abundance similar to that of the total mesozooplankton, although meroplankton (mainly brachyuran zoeae) dominated at station 1 during all the months and in June (rainy season) at all stations.

Confirming the observation that zooplankton overall density and biomass declined during the transition from dry to rainy season, the KruskalWallis ANOVA showed significant effects of the factor "Month" on microzooplankton density ( $\mathrm{p}=$ 0.04 ), and on mesozooplankton biomass ( $\mathrm{p}=$ 0.002), both with maximum values in February (dry season, Fig. 3). The factor "Month" also had a significant effect on chlorophyll- $a$ concentrations $(\mathrm{p}=0.038)$, but with maximum values in May (rainy season). Since the temporal variability presented in the factor "Month" is on a seasonal scale, this indicates that a significant seasonal variability occurred in several important parameters related to the phyto-, microzoo- and mesozooplankton. However, the remaining plankton parameters (phytoplankton cell density, microzooplankton biomass, and mesozooplankton density) did not show significant effects of the factor "Month". Surprisingly, no significant effect of the factor "Station" could be detected. The spatial effect was probably being masked by the high temporal variability. 
Table 4 - Zooplankton species list of the Maracajaú reef ecosystem (Brazil).

\begin{tabular}{|c|c|}
\hline \multicolumn{2}{|c|}{ Foraminifera } \\
\hline $\begin{array}{l}\text { Bolivina } \mathrm{sp} . \\
\text { Esponides } \mathrm{sp} . \\
\text { Remaneica } \mathrm{sp} . \\
\text { Spirillina } \mathrm{sp} .\end{array}$ & $\begin{array}{l}\text { Trilocularina sp. } \\
\text { Tetromphalus bulloides d'Orbigny, } 1826 \\
\text { Textularia sp. }\end{array}$ \\
\hline \multicolumn{2}{|c|}{ Tintinnina } \\
\hline $\begin{array}{l}\text { Leprotintinnus nordqvisti (Brandt 1906) } \\
\text { Codonella amphorella } \text { Biedermann, 1893 } \\
\text { Tintinnopsis compressa Daday, } 1887 \\
\text { Tintinnopsis directa } \text { Hada } 1932 \\
\end{array}$ & $\begin{array}{l}\text { Tintinnopsis mortensenii Schmidt } 1901 \\
\text { Tintinnopsis tocantinensis Kofoid and Campbell } 1929 \\
\text { Codonellopsis morchella (Cleve 1900) } \\
\text { Favella ehrenbergi (Claparède and Laachmann, 1858) }\end{array}$ \\
\hline \multicolumn{2}{|c|}{ Cnidaria } \\
\hline \multicolumn{2}{|c|}{ Liriope tretraphylla (Chamisso and Eysenhardt, 1821) } \\
\hline \multicolumn{2}{|c|}{ Platyhelminthes } \\
\hline \multicolumn{2}{|l|}{ Convoluta sp. } \\
\hline \multicolumn{2}{|c|}{$\begin{array}{l}\text { Nematoda } \\
\text { Polychaeta (larvae) } \\
\text { Mollusca }\end{array}$} \\
\hline \multicolumn{2}{|l|}{$\begin{array}{l}\text { Creseis acícula (Rang, 1828) } \\
\text { Gastropoda (veligers) }\end{array}$} \\
\hline \multicolumn{2}{|c|}{ Copepoda } \\
\hline $\begin{array}{l}\text { Nannocalanus minor (Claus, 1863) } \\
\text { Subeucalanus pileatus (Giesbrecht, 1888) } \\
\text { Parvocalanus crassirostris (F. Dahl, 1894) } \\
\text { Paracalanus quasimodo Bowman 1971 } \\
\text { Clausocalanus furcatus (Brady, 1883) } \\
\text { Temora stylifera (Dana, 1849) } \\
\text { Centropages velificatus (Oliveira 1947) } \\
\text { Pseudodiaptomus acutus (F. Dahl, 1894) } \\
\text { Pontella atlantica (Milne-Edwards, 1840) } \\
\text { Labidocera fluviatilis F. Dahl, 1894 } \\
\text { Calanopia americana F. Dahl, } 1894 \\
\text { Acartia lilljeborgi Giesbrechti, } 1892\end{array}$ & $\begin{array}{l}\text { Oithona nana Giesbrechti, } 1892 \\
\text { Oithona hebes Giesbrecht, } 1891 \\
\text { Oithona oswaldocruzi Oliveira, } 1945 \\
\text { Oithona oculata Farran, } 1913 \\
\text { Oithona sp. (copepodite) } \\
\text { Corycaeus giesbrechti F. Dahl, } 1894 \\
\text { Hemycyclops thalassius Vervoort and Ramirez } 1966 \\
\text { Euterpina acutifrons (Dana,1847) } \\
\text { Tigriopus sp. } \\
\text { Caligus sp. } \\
\text { Copepoda (nauplii) }\end{array}$ \\
\hline
\end{tabular}

\begin{tabular}{lc}
\hline & Cirripedia \\
\hline Balanus sp. (larvae) & $\begin{array}{l}\text { Isopoda (larvae) } \\
\text { Stomatopoda }\end{array}$ \\
\hline Alima sp. (larvae) & Decapoda \\
\hline Lucifer faxoni Borradaile, 1915 & Brachyura (zoeae) \\
Farfantepenaeus sp. (larvae) & Brachyura (megalopa) \\
Alpheidae (larvae) & Paguridae (larvae) \\
Porcellanidae (larvae) & Bryozoa \\
\hline & Echinodermata (larvae) \\
\hline Membraniphora sp. (larvae) & Chaetognatha \\
\hline Sagitta tenuis Conant, 1896 & Larvacea \\
\hline Oikopleura dioica Fol, 1872 & Oikopleura longicauda Vogt, 1854 \\
\hline
\end{tabular}

Multivariate community structure analysis confirmed the existence of strong seasonal effects acting upon the micro- and mesozooplankton in the study area. Multidimensional scaling (MDS) plots (Figs. 4 and 5) and Cluster analysis showed that the formation of sample groups was influenced strongly by the factor "Month", while the factor "Station" (spatial distribution) had little 
overall influence on group formation.

Confirming the results of MDS and Cluster analysis, the one-way ANOSIM tests, run with 999 permutations, showed that the factor "Month" had a significant effect on group formation for microand mesozooplankton communities $(\mathrm{p}=0.01$ for both communities). No significant effect of the factor "Station" on group formation could be detected.

\section{DISCUSSION}

The only coral reefs of the South Atlantic occur at the Brazilian Exclusive Economic Zone (EEZ). Brazilian coral reefs have three distinctive characteristics: 1) they display a low diversity in corals (18 coral species) compared to Caribbean reefs; 2) the major reef builders are coral species that are endemic for Brazilian waters, and 3) they are predominantly composed of massive forms (Leão et al., 2003). Of the six reef-building species identified in Maracajaú, three are endemic for Brazil (S. stellata, F. gravida and M. hispida) and are the most common forms in almost all existing Brazilian reefs. M. hispida occurs from Rocas Atoll (Northeastern Brazil) to the coast of Santa Catarina State (Southern Brazil), presenting the widest spatial distribution. S. stellata and $F$. gravida are the most common corals in shallow intertidal pools of the reef tops and are resistant to huge variations in temperature, salinity and water turbidity.

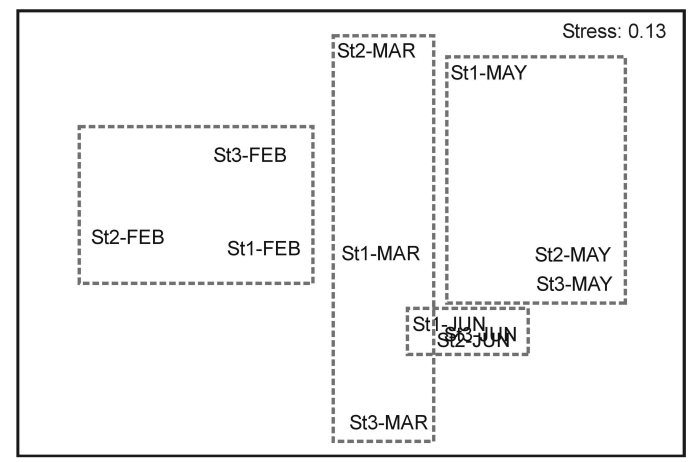

Figure 4 - Multidimensional Scaling (MDS) plot of the microzooplankton (65 $\square \mathrm{m}$ ) samples collected off Maracajaú, Brazil. Station and month are given for each sample. BrayCurtis similarity between samples were calculated based on a density matrix of 50 taxa $\mathrm{x} 12$ samples. $\mathrm{St}=$ Station, FEB=February, MAR=March, JUN=June.

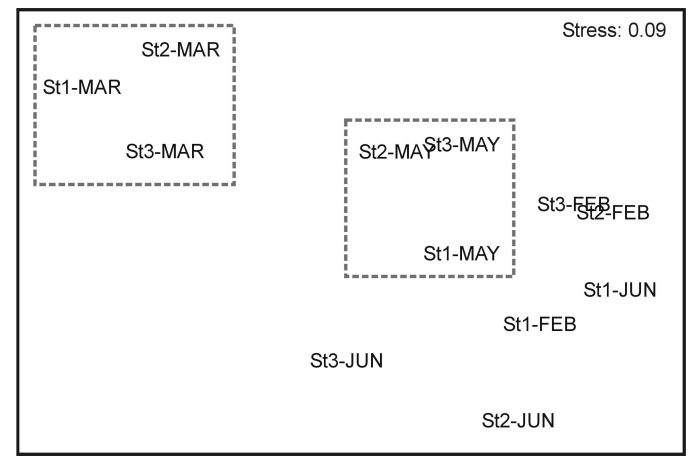

Figure 5 - Multidimensional Scaling (MDS) plot of the mesozooplankton (120 $\square \mathrm{m})$ samples collected off Maracajaú, Brazil. Station and month are given for each sample. BrayCurtis similarites between samples were calculated based on a density matrix of 40 taxa $\mathrm{x} 12$ samples. St=Station, FEB=February, MAR=March, JUN=June. 
The low coral diversity in Maracajaú, compared to other reef systems in Brazil is the consequence of the monopolization of niches by one or few species. According to Grigg (1983), reef systems with low diversity are considered climax communities, space have been dominated by one or two species as a result of their competitive superiority in the absence of frequent disturbance. According to Connell (1980), Ricklefs (1980), and Wilson (1992), disturbance rather than stability seems to enhance the species richness under certain conditions. If disturbances are rare and small, competition leads to the elimination of inferior competitors as the community moves to equilibrium. In disturbed areas, a greater range of species from all the succession stages and all competitive abilities is maintained because the invasion of species increases and elimination by competition does not occur. The intermediate disturbance hypothesis (Connell, 1978) has been suggested as the explanation for the high diversity of coral reefs.

The cosmopolitan species Porites astreoides, $P$. branneri and Agaricia agaricites found at Maracajaú occur in both Brazilian and Caribbean reefs, and in Brazil they have a secondary role in reef building (Leão et al., 2003).

Siderastrea stellata, Porites astreoides and the hydrocoral Millepora alcicornis, and Palythoa were found by Laborel (1969) in the Maracajaú area. Thus, the present study contributed with four new occurrences of corals Agaricia agaricites, Porites branneri, Favia gravida, and Mussismilia hispida for the Maracajaú reefs. Although very common to other Northeastern coastal areas, these species were not reported by Laborel (1969), probably because the sampling was performed only once, when the water was very turbid and the visibility was less than one meter.

According to Achituv and Dubinsky (1990), slight changes in the reef environment may have detrimental effects on the health of entire coral communities. Lower salinities as observed in the rainy season for Maracajaú, due to floods, runoff from land and river discharge, prevented reef development on local and regional scale, especially in the vicinity of river outlets (Squires, 1962; Milliman, 1973). Sedimentation patterns also interfere on the reef development (Stoddart, 1969, Dubinsky, 1990). The coexistence of corals in highly turbid ecosystem in Northeastern Brazil, mainly during the rainy season, challenges coral researchers to explain how these species succeed in this environmental condition.

The Maracajaú reefs are ecologically important ecosystems and man has had a long association with them. However, some reefs located near the coastal population are showing increasing signs of stress. Reef fish populations in this area have been greatly decreased due to overfishing (Feitosa et al., 2003). So, fishermen are using fish traps with small mesh sizes, which catch even the small juvenile fish and/or explosives or poisons (Feitosa et al., 2003). These practices kill virtually all fish and severely damage the corals in the surrounding areas.

There are few natural disturbances, which cause significant damage to coral reefs, like the El Niño South Oscillation (ENSO) effect increasing the water temperature. The stable isotopes analysis of $F$. gravida indicated the occurrence of thermal stress in 2000, due to the temperature rise. In Brazil, coral bleaching has long been observed along the coast. The first study was performed in 1993 by Migotto (1997), when an extensive bleaching of Mussismilia hispida and Madracis decactis occurred in São Paulo State (Southern Brazil). The author concluded that the temperature rise was the major cause of the bleaching, and reported that the colonies recovered six months later. Other bleaching events are described by Leão et al. (2003) in North Bahia and Abrolhos (Eastern Brazil) in 1998. In North Bahia, extensive coral bleaching due to temperature rise occurred affecting mainly Agaricia agaricites ( 80\%), Mussismilia hispida ( 60 to 20\%) and Siderastea stellata ( 45 to $15 \%$ ). In Abrolhos, the degree of bleaching was also high and the most affected species were Porites branneri (80\%), M. hispida (85\%, of which $45 \%$ totally and $49 \%$ partially bleached), M. hartii ( 75\%) and P. astreoides (all colonies affected). No data on the recovery were available.

This bleaching causes great damage to the ecosystem, as coral reefs provide habitats for a large variety of organisms (Brown and Odgen, 1993). These organisms rely on corals as a source of food and shelter. Generally, corals can obtain food in a variety of ways. Reef-building corals rely on the photosynthetic products of zooxanthellae for the majority of their nutrients. However, corals are also suspension feeders and also capture zooplankton for food. Most corals feed at night, when most zooplankton organisms ascend to 
surface waters and become available for capture. Zooplankton is an important component of the reef ecosystem and is available in conspicuous abundance for planktivorous animals in many reef communities. Among the reef animals feeding on plankton, there are numerous planktonic and benthic filtering invertebrates, benthic sediment feeders (including corals), abundant populations of planktivorous fishes, and all fish larvae (Sorokin, 1990). Several studies on the plankton abundance all over the world have shown that coral reefs remove 20 to $80 \%$ of the plankton from water passing over reef crests and flats (Tranter and George, 1972; Glyn, 1973; Johannes and Geber, 1974; Lefreve, 1985). If these filtration efficiencies are realistic, the coral reef may be regarded as a huge sieve capable of differential filtration, and thus its study in Brazil is of great importance. Nevertheless, the coral reef zooplankton in northeastern Brazil has been less studied than the plankton of estuaries and of open oceanic waters.

The sampling period in the present study at the Maracajaú reef area covered successive months from the dry to rainy season, the rainfall being an important physical regulator of the plankton dynamics. The rainy season of 2000 was characterized by high rainfall $(>250 \mathrm{~mm})$ according to data from INMET (Institute of Meteorology), and considerable riverine discharge (seen by the visible turbid plume of the Maxaranguape River). During this period, the area was influenced by an estuarine indicator group (Parvocalanus crassirostris, Acartia lilljeborgi, Euterpina acutifrons, Oithona oswaldocruzi). This same group was reported by Neumann-Leitão et al., (1992) and Silva et al. (2004) in Suape reef area in Pernambuco State during the rainy season. In contrast, the dry season brought very little rainfall $(<50 \mathrm{~mm})$, and was characterized by some intrusion from the oligotrophic North of Brazil Current, the North branch from the South Equatorial Current.

In the present study, phytoplankton biomass in terms of chlorophyll- $a$ was higher during the rainy season. The broad phytoplankton biomass patterns observed were the same as described by Sassi et al. (1991) in the reef area of Ponta de Seixas in Paraíba State, where chlorophyll $a$ was also higher in the rainy season. However, higher cell counting values were registered in the dry season. For zooplankton, the total net plankton biomass increased in the dry season as a result of an increase in numbers of nauplii and juvenile copepods, mainly Oithona sp. Similar patterns were found by Nascimento-Vieira (2000) and Porto Neto et al. (2000) in the reef area of Tamandare in the south of Pernambuco State (Northeastern Brazil). The present data suggest a dynamic relationship between the plankton community characteristic of inshore water trapped by the coastal boundary layer and more offshore plankton communities. The extent of the inshore plankton community changed under the influence of meteorological (wind speed and direction) and hydrographic (terrestrial runoff) forcing events. Thus, the plankton community indicated a continuous influence of the estuarine plume in the Maracajaú reef area, and this could be one of the causes of the coral community low diversity, as this condition only allowed the existence of resilient species.

The values of the biotic and abiotic variables observed did not indicate a status of drastic degradation of the ecosystem and were within the range expected for a tropical nearshore coral reef ecosystem. However, it was observed that the Maracajaú reefs and adjacent ecosystems suffered a large variety of human impacts on diverse spatial and temporal scales, which create multiple acute and potential threats. The main problems were the anchoring and traffic of small private motor boats on the reef, and the leakage of oils and fuels. Scuba diving, artisanal and sports fishery were locally important activities, which were being regulated in the context of the management of the Maracajaú Marine Protected Area. The occurrence of oil spills by tankers and large freighters passing offshore had been reported by local people. The illegal destruction of estuarine mangroves for land fills and urbanization was a constant threat to the Maracajaú reef system. Therefore, much care must be taken to control and reduce the tourism.

Another threat to the Maracajaú reef ecosystem was the untreated sewage from cities and villages located along the coast, causing an increased nutrient input for the reef biota, as seen in the present study, when levels much higher than surrounding sea water were registered. This is a common problem in many coastal areas of Brazil (Costa Junior, 1998; Porto Neto et al., 2000, among others). 


\section{RESUMO}

Esta pesquisa apresenta informações básicas sobre as condições hidrológicas e sobre as comunidades de corais e do plâncton no ecossistema recifal de Maracajaú (Nordeste do Brasil). Estudos foram realizados de fevereiro a junho de 2000 , cobrindo o período de transição das estações seca a chuvosa. Nesta area existe uma formação de recife de coral afastada da costa, onde os corais foram observados in loco e amostras de água foram coletadas para a obtenção de dados hidrológicos e planctônicos. Foram identificadas seis espécies de escleractíneos. Análises com isótopos estáveis em fragmentos de carbonato de Favia gravida mostraram que este coral está sob estresse termal severo. As concentrações de clorofila- $a$ variaram de $1,1 \mathrm{mg} \mathrm{m}^{-3}$ a $9,3 \mathrm{mg} \mathrm{m}^{-3}$, com maiores valores durante o período chuvoso. A biomassa média em peso úmido do zooplâncton foi de $117,0 \mathrm{mg} \mathrm{m}^{-3}$ para o microzooplâncton e de $15,7 \mathrm{mg} \mathrm{m}^{-3}$ para o mesozooplâncton. Foram identificados 136 taxa do fitoplâncton e 61 do zooplâncton. Forçantes sazonais determinaram a estrutura da comunidade do phyto- micro- e mesozooplâncton muito mais do que o gradiente costa-oceano.

\section{ACKNOWLEDGMENTS}

The authors thank Dr. Prof. Constantine Herbert Fernando from Waterloo University (Canada) for reviewing the English and the text. Dr. Alcides da Nóbrega Sial from the Federal University of Pernambuco for the stable isotope analysis. The Boticário Foundation (Brazil) for supporting this project.

\section{REFERENCES}

Achituv, Y. and Dubinsky, Z. (1990), Evolution and zoogeography of coral reefs. In- Ecosystems of the World 25: Coral Reefs, ed. Z. Dubinsky. Elsevier, Amsterdam, pp 1-9.

Brown, B. E. and Odgen, J. C. (1993), Coral Bleaching. Scient. Am., 269, 64-70.

Castro, C. B. and Pires, D. O. (2001), Brazilian Coral Reefs: What we already know and what is still missing. Bull. Mar. Science, 69, 357-371.

Clarke, K. R. and Warwick, R. M. (1994), Change in Marine Communities: An approach to statistical analysis and interpretation. Natural Environment Research Council, U.K. , 1-144.
Connell, J. H. (1978), Diversity in tropical rain forests and coral reefs. Science, 199, 1302-1310.

Connell, J. H. (1980), Diversity and the coevolution of competitors or the ghost of competition past. Oikos, 35, 131-138.

Costa Junior, O. S. (1998), Efeitos da percolação da água do lençol freático nos recifes de corais das praias de Guarajuba e Papa Gente, litoral norte do estado da Bahia. MSc Thesis, Universidade Federal da Bahia, Salvador, Brazil.

Craig H (1957) Isotopic standards for carbon and oxygen and correction factors for mass spectrometric analysis of carbon dioxide. Geochim Cosmochim Acta 12, 133-149.

Dubinsky, Z. (1990), Ecosystems of the World 25: Coral Reefs. Elsevier, Amsterdam.

Feitosa, C. V.; Pimenta, D. A. S. and Araújo, M. E. (2003), Ictiofauna recifal dos Parrachos de Maracajaú (RN): inventário, estrutura da comunidade e interferência antrópica. Arq. Ciên. Mar, 35, 1-17.

Glynn, P.W. (1973), Ecology of Caribbean coral reef: plankton community with evidence for depletion. Mar. Biol., 22, 1-23.

Grasshoff, K.; Ehrhardt, M. and Kremling, K. (1983), Methods of Seawater Analysis. Verlag Chemie, $2^{\text {nd }}$ edition.

Grigg, R. W. (1983), Community structure, succession and development of coral reefs in Hawaii. Mar. Ecol. Prog. Ser., 11, 1-14.

Goreau, T. F.; Goreau, N. I. and Goreau, T. J. (1979), Corals and Coral Reefs. Scient. Am., 241, 124-136

Horibe, Y. and Oba, T. (1972), Temperature scale aragonite-water and calcite-water systems Fossils. InPrinciples of Isotope Geology, ed. G. Faure. London, John Wiley and Sons, pp 69-79.

Johannes, R. E. and Geber, R. P. (1974), Import and export by Eniwetok reef Community. Proc. 2nd Int Coral Reef Symp 1, 97-104.

Kohn, A. J. (1997), Why are coral reef communities so diverse? In - Marine Biodiversity, Patterns and Processes, eds. R. F. G. Ormond, J. D. Gage, J. D. Angel. Cambridge University Press, Cambridge (UK), pp 201-215.

Laborel, J. (1965), Note préliminaire sur lês récifs de grés et récifs de coraux dans lê Nord-Est brésilien. Rec. Trav. Stat. Mar. Endoume, 37(53), 341-344.

Laborel, J. (1969), Les peuplements de Madréporaires des côtes tropicales du Brésil. Ann. Univ. d'Abidjan (Ser. E), 2(3), 1- 261.

Leão, Z. M. A. N.; Kikuchi, R. K. P. and Testa, V. (2003), Corals and coral reefs of Brazil. In- Latin American Coral Reefs, ed. J. Cortés. Elsevier, Amsterdam, pp. 9-52.

Lefreve, M. (1985), Spatial variability of zooplanktonic populations in the lagoons of a high island (Moorea, French Polynesia). Proc.5th Int Coral Reef Symp 6, pp. 39-45. 
Maida, M. and Ferreira, B. P. (1997), Coral Reefs of Brazil: Overview and Field Guide. Proc. $8^{\text {th }}$ Int. Coral Reef Symp., Panamá, pp. 263-274.

Mayal, E. M.; Gomes, P. B. and Pereira, L. C. C. (2000), Reefs of Pernambuco-Brazil - Part I Scleractinia common in the region of Tamandaré (South Coast of the State of Pernambuco). Trab. Oceanog. Univ. Fed. PE, 28 (2), 51-65.

McCrea, J. M. (1950), On the isotope chemistry of carbonates and a paleotemperature scale. J Chem Physis, 18, 849-857.

Migotto, A. (1997), Anthozoa bleaching on the southern coast of Brazil in the summer 1994. Proc. $6^{\text {th }}$ Int. Conf. Coelenterate Biol., pp.329-335.

Milliman, D. (1973), Caribbean coral reefs. In- Biology and Geology of Coral Reefs, eds. O. A. Jones and R. Endean. Academic Press, New York, v.1, pp.1-50.

Nascimento-Vieira, D. A. (2000), Macrozooplâncton recifal da baía de Tamandaré, Pernambuco - Brasil. $\mathrm{PhD}$ thesis, Federal University of Pernambuco, Recife, Brazil.

Neumann-Leitão, S.; Gusmão, L. M. O. and Nascimento-Vieira, D. A. (1992), Zooplâncton dos estuários dos rios Massangana e Tatuoca, Suape (PE Brasil). Arq. Biol. Tecnol., 35 (2):341-360.

New, T. R. (1995), An Introduction to Invertebrate Conservation Biology. Oxford University Press, Oxford, 194p.

Omori, M. and Ikeda, T. (1984), Methods in marine zooplankton ecology. Wiley-Interscience Publication, New York, 331p.

Parsons T. R. A. and Strickland J. D. H. (1963), Discussion of the spectrophotometric determination of the marine plant pigments, with revised equations for ascertaining chlorophylls and carotenoids. J. Mar. Res., 21(31), 155-163.

Porto Neto, F. F.; Neumann-Leitão, S.; NascimentoVieira, D. A.; Silva, A. P.; Silva, T. A. and Moura M. C. O. (2000), Zooplâncton recifal de Tamandaré - PE (Brasil) e a influência dos manguezais na sua biodiversidade e biomassa. Mangrove 2000 Symp., Sustainable Use of Estuaries and Mangroves: Challenges and Prospects, CDRom, 10p.

Prates, A. P. L. (2003), Atlas dos Recifes de Coral nas Unidades de Conservação Brasileiras. Ministério do Meio Ambiente.

Richmond, R. H. (1993), Coral Reefs: Present Problems and Future Concerns Resulting from Anthropogenic Disturbance. Am. Zool., 33, 524-536.

Ricklefs, R. E. (1980), Geographical variation in clutch size among passerine birds: Ashmole's hypothesis. Auk, 97, 38-49.
Sassi, R.; Veloso, T. M. G.; Melo, G. N. and Moura, G. F. (1991), Variações diurnas do fitoplâncton e de parâmetros hidrológicos em recifes costeiros do Nordeste do Brasil. 5th Encontro Brasileiro de Plâncton, Ed. Universitária, pp. 61-96.

Silva, A. P.; Neumann-Leitão, S.; Schwamborn, R.; Gusmão, L. M. O. and Silva, T. A. (2004), Mesozooplankton of an impacted bay in North Eastern Brazil. Braz. Arch. Biol. Technol., 47 (3), 485-493.

Sorokin, Y. I. (1990), Plankton in the reef ecosystems. In- Ecosystems of the World 25: Coral Reefs, ed. Z. Dubinsky. Elsevier, Amsterdam, pp 291-327.

Squires, D. F. (1962), Corals at the mouth of the Rewa River, Viti Levu, Fiji. Nature, 195, 361-362.

Steemann-Nielsen, E. (1952), The use of radioactive carbon $\left({ }^{14} \mathrm{C}\right)$ for measuring organic production in the sea. J. Cons. Int. Expl. Mer, 18(2), 117-140.

Stoddart, D. R. (1969), Ecology and morphology of recent coral reefs. Biol.1 Rev., 44, 433-498.

Strickland, J. D. H. and Parsons, T. R. (1965), A manual of seawater analysis. Bull. Fish. Res. Board Canada, 125, 1-205.

Strickland, J. D. H. and Parsons, T. R. (1972), A practical handbook of seawater analysis. Bull. Fish. Res. Board .Canada, 167, 207-211.

Testa, V. (1997), Calcareous algae and corals in the inner shelf of Rio Grande do Norte, NE Brazil. Proc. 8th Int. Coral Reef Symp 1, 737-742.

Tranter, D. J. and George, J. (1972), Zooplankton abundance at Kavaratti and Kalpeni Atolls in the Laccadives. Proc. Symp. Coral Reefs Mar Biol Assoc India, pp. 239-256.

Vollenweider, R. A.; Talling, J. F. and Westlake, D. F. (1974), A manual in method for measuring primary production in aquatic environments, including a chapter on bacteria. International Biological Program Handbook, Oxford, $2^{\text {nd }}$ ed. $225 \mathrm{p}$.

Wells, J. W. (1957), Coral reefs. Mem. Geol. Soc. America, 67(1), 1087-1104.

Wilson, E.O.(1992). The Diversity of Life. Harvard Univ. Press, Cambridge, Mass., U.S.A.

Zar, J. H. (1996), Biostatistical Analysis. $3^{\text {rd }}$ ed., New Jersey, Prentice-Hall, 718p.

Received: April 04, 2006; Revised: January 11, 2007; Accepted: September 20, 2008. 